\title{
STRATEGI PENERAPAN AKAD MUSYARAKAH PADA BIDANG PERTANIAN DI LEMBAGA KEUANGAN MIKRO AGRIBISNIS (LKMA) AMANAH MANDIRI SEKARPUTIH, NGANJUK
}

\author{
Oleh \\ Alfin Yuli Dianto \\ Institut Agama Islam Pangeran Diponegoro Nganjuk \\ alfinmaskur@iaipd-nganjuk.ac.id
}

\begin{abstract}
Lately, agricultural businesses can be facilitated by Agribusiness Microfinance Institutions (LKMA). This makes it easier for farmers to get capital for business development. However, what must be considered is how the agreement used or in Islamic economics is called a musyarakah contract (cooperation agreement) between the farmers and LKMA. Of course this must be in accordance with the terms and conditions in the sharia process. Researchers found that in planning the Musharaka contract financing in agriculture in LKMA was still lacking. This is because many customers or partners do not know about musharakah. In addition, the implementation of musharaka financing has not been implemented well, which in turn has an impact on the lack of maximum agricultural output.
\end{abstract}

Keywords: Agribusiness Financial Institution, Musharakah Contract, Agriculture Sector

\begin{abstract}
Abstrak
Belakangan ini usaha pertanian dapat difasilitasi oleh Lembaga Keuangan Mikro Agribisnis (LKMA). Hal itu mempermudah para petani dalam mendapatkan modal untuk pengembangan usaha. Namun, yang harus diperhatikan adalah bagaimana perjanjian yang digunakan atau dalam ekonomi syariah disebut akad musyarakah (perjanjian kerjasama) antara pihak petani dengan LKMA. Tentu hal ini harus sesuai dengan syarat dan ketentuan dalam proses syariah. Peneliti menemukan bahwa dalam perencanaan pembiayaan akad musyarakah di bidang pertanian di LKMA masih kurang. Hal ini karena banyak nasabah atau mitra yang belum tahu tentang
\end{abstract}


musyarakah itu sendiri. Selain itu pelaksanaan pembiayaan musyarakah belum terlaksana dengan baik yang akhirnya berdampak pada kurang maksimalnya hasil pertanian.

Kata Kunci: Lembaga Keuangan Agribisnis, Akad Musyarakah, Bidang Pertanian

\section{Pendahuluan}

Sistem ekonomi syariah atau sistem ekonomi islam, sebagai suatu sitem yang merujuk pada syari'at, yaitu petunjuk wahyu, diyakini para penganutnya sebagai suatu sistem yang memiliki kekuatan dan kemampuan memakmurkan dan mensejahterahkan para pengamalnya, baik muslim maupun nonmuslim. Ekonomi syariah yang diyakini sebagai sistem ekonomi yang mendapat panduan nilai dan norma kehidupan yang datang dari Yang Mahabesar dan Maha adil, Allah SWT. Tujuanya pun tentu untuk menciptakan dan mewujudkan kesejahteraan dunia akhirat dalam kehidupan masyarakat yang berkeadilan. Denagn kata lain, sistem ekonomi syariah diyakini lebih memberikan jaminan bagi terwujudnya kesejahteraan dan keadilan masyarakat. Bahkan, karena bersifat universal dan dapat menjadi rahmat bagi sekalian alam, sistem syariah Islam bukan hanya dapat menjamin terwujudnya kesejahteraan dan keadilan dalam ruang lingkup masyarakat yang beragama islam, melainkan dapat dilaksanakan dalam semua lingkungan dan komunitas. ${ }^{1}$

Perbankan Islam memiliki sejarah yang unik. Dikatakan unik karena kembaga ini memiliki karakteristik tersendiri sehingga berbeda dengan perbankan konvensional, sehingga acuan perbankan islam bukanlah suatu sistem yang merujuk dari perbankan konvensional itu sendiri, akan tetapi dari baitutamwil. Lembaga keuangan bank dan non bank merupakan lembaga keuangan yang menyediakan dana baik itu digunakan untuk investasi atau untuk konsumsi. Lembaga keuangan dengan prinsip syariah mulai masuk di Indonesia. Perkembangan lembaga keuangan syariah ini cukup pesat,ini dibuktikan dengan adanya banyak lembaga-lembaga keuangan syariah

\footnotetext{
${ }^{1}$ Prof. Dr. H. Juhaya S. Pradja, M.A, Ekonomi Syariah, Bandung;
} Pustaka Setia,2012,73 
di berbagai daerah. Singkatnya, tujuan syariah adalah menjamin keselamatan umat manusia secara fisik, moral dan spiritual di dunia ini dan untuk menyiapkan perjumpaan dengan Allah di hari yang akan datang. ${ }^{2}$

Pembangunan pertanian merupakan salah satu sektor utama dalam pembangunan sosial, hal ini berkaitan dengan sektor pertanian dalam penyediaan lapangan pekerjaan, juga sebagai pengahasil pangan serta sektor pertanian yang lebih fleksibel. Salah satu kegiatan ekonomi sektor riil yang diharapkan dapat menggunakan pembiayaan syariah adalah bidang pertanian. Sekarang bidang pertanian masih memainkan peran sangat strategis dalam perekonomian nasional. Pertanian tetap menjadi andalan sebagai sumber pendapatan dan mata pencaharian di sebagian penduduk Indonesia. Dan petani juga sangat penting karena sebagai sumber bahan pangan.

Seiring berkembangya zaman, banyak lembaga lembaga keuangan syariah yang menggunakan beberapa pembiayaan, salah satunya adalah pembiayaan musyarakah. Yang kali ini diterapkan di dalam bidang pertanian dan sektor usaha kecil, maupun menengah. Perkembangan lembaga-lembaga keuangan syariah ini berdiri sangat pesat, seperti halnya dengan lembaga keuangan mikro agribisnis yang ada di daerah Bagor sekarputih tersebut. Lembaga tersebut terdapat beberapa pembiayaan, yang salah satunya menggunakan akad musyarakah pada bidang pertanian. Berdasarkan latar belakang diatas maka dari berbagai aspek tersebut penelitian ini mencoba untuk meneliti hal tersebut mengenai bagaimana strategi penerapan akad musyarakah yang ada pada Lembaga Keuangan Mikro Agribisnis Syari'ah Amanah Mandiri, Desa Sekarputih, Kecamatan Bagor, Kabupaten Nganjuk.

\section{Metode Penelitian}

Penelitian pada hakekatnya mencari jawaban atas masalah yang menuntut jawaban yang benar, setidak-tidaknya mendekati kebenaran yang logis menurut penalaran manusia dan didukung oleh

\footnotetext{
${ }^{2}$ Mahmoud M. Ayoub, ibid., hlm.174.
} 
fakta empiris. Penelitian kualitatif adalah jenis penelitian yang menghasilkan penemuan-penemuan yang tidak dapat di capai dengan menggunakan prosedur-prosedur statistik atau dengan cara lain dari kuantifikasi (pengukuran). Peneliti menggunakan pendekatan kualitatif karena data yang diperoleh dari penelitian kualitatif seperti hasil dari observasi, wawancara, dan dokumentasi, di susun peneliti di lokasi penelitian, tidak dituangkan dalam bentuk dan bilangan statistik. Jenis penelitian ini menggunakan Grounded Theory, dengan menghubungkan orientasi pengembangan atau kategori, pengumpulan data yang sistematik dan analisis dikembangkan dari prosedur sperti aksial, open tertentu. Permasalahan penelitian adalah permasalahan yang terjadi pada saat penelitian dilaksanakan, sehingga pemanfaatan temuan penelitian ini berlaku pada saat itu pula yang belum relevan bila digunakan untuk waktu yang akan datang. Dalam penelitian ini bermaksud mendiskripsikan strategi penerapan akad musyarakah di LKMA Sekarputih.

Penelitian ini mengambil lokasi di Lembaga Keuangan Mikro Agribisnis Amanah Mandiri Sekarputih Nganjuk. Peneliti memilih lokasi tersebut karena dianggap LKMA dapat memberikan kajian yang menarik tentang pelaksanaan pembiayaan yang khususnya untuk bidang pertanian dengan menggunakan akad musyarakah.Seperti beberapa petani yang juga menjadi peminjam atau melakukan pembiayaan musyarakah. Penelitian ini dilaksanakan mulai tanggal 23 Januari sampai 22 Februari 2018.

Dalam penelitian kualitatif, jenis sumber data yang berupa manusia dalam penelitian pada umunya sebagai responden (respondent.). Posisi sumber data yang berupa manusis (narasumber) sangat penting peranya sebagai individu yang memiliki informasinnya . Peneliti dan nara sumber memiliki kedudukan yang sama, oleh karena itu narasumber bukan sekedar memberiksn tsnggapan pada yang diminta peneliti, tetapi ia bisa lebih memilih arah dan selera dalam menyajikan informasi yang ia miliki. Data dan sumber data yang diperoleh oleh peneliti dari lapangan dengan observasi atau wawancara. Peneliti menggunakan data ini untuk mendapatkan 
informasi tentang pembiayaan musyarakah di LKMA Amanah Mandiri Sekarputih.

Adapun sumber data yang digunakan oleh peneliti adalah pertama, sumber data primer, yaitu data yang langsung dikumpulkan oleh peneliti (atau petugasnya) dari sumber pertamanya.3 Adapun yang menjadi sumber data primer dalam penelitian ini adalah Puspitio selaku manajer di LKMA Sekarputih. Kedua, sumber data sekunder, yaitu data yang langsung dikumpulkan oleh peneliti sebagai penunjang dari sumber pertama. Dapat juga dikatakan data yang tersusun dalam bentuk dokumen-dokumen berupa data anggota LKMA. Dalam penelitian ini, dokumentasi dan wawancara sebagai sumber data.

\section{Hasil Dan Pembahasan}

\section{Lembaga Keuangan Syari'ah}

Menurut SK Menkeu RI No.792 tahun 1990,lembaga keuangan adalah semua badan yang kegiatannya bidang keuangan, melakukan penghimpunan dan penyaluran dana kepada masyarakat terutama guna membiayai investasi perusahaan. ${ }^{4}$ Lembaga keuangan syariah (LKS) merupakan suatu lembaga keuangan yang prinsip operasinya berdasarkan pada prinsip-prinsip syariah yang harus terhindar dari unsur riba, gharar, maisir dan akad yang bathil. Menurut Dewan Syariah Nasional (DSN), Lembaga Keuangan Syariah adalah sebuah Lembaga keuangan yang mengeluarkan produk-produk syariah dan telah mendapat izin operasional sebagai Lembaga Keuangan Syariah.

Lembaga keuangan syariah didirikan dengan tujuan mempromosikan dan mengembangkan penerapan prinsip-prinsip islam, syariah dan tradisinya ke dalam transaksi keuangan dan perbankan serta bisnis yang terkait. Adapun yang dimaksud dengan prinsip syariah adalah prinsip hukum Islam dalam kegiatan perbankan

\footnotetext{
${ }^{3}$ Sumadi Siryabrata, Metode Penelitian,Jakarta: Rajawali,1987,93.

${ }^{4}$ Andri Soemitra, Bank Dan Lembaga Keuangan Syariah, Kencana,, Jakarta,2014,hlm. 27
} 
dan keuangan berdasarkan fatwa di bidang syariah. Prinsip syariah dianut oleh lembaga keuangan syariah dilandasi oleh nilai-nilai keadilan, kemanfaatan, keseimbangan, dan keuniversalan (rahmatan lil'alamin).

Nilai keadilan tercermin dari penerapan imbalan dasar bagi hasil dan pengambilan margin keuntungan yang disepkati bersama antara lembaga keuangan syariah dan nasabah. Kemanfaatan tercermin dari kontribusi maksimum lembaga keuangan syariah bagi pengembangan ekonomi nasional di samping aktivitas sosial yang diperankannya. Keseimbangan tercermin dari penempatan nasabah sebagai mitra usaha yang berbagi keuntungan dan resiko secara berimbang. Keunivesalan tervermin dari dukungan bank syariah yang tidak membeda-bedakan suku, agama, ras, golongan agama dalam masyarakat dengan prinsip islam sebagai rahmatan lil alamin.

Prinsip utama yang dianut oleh lembaga keuangan syariah dalam menjalankan kegiatan usahanya adalah:

1) Bebas "maghrib". Maysir (spekulasi); secara bahasa maknanya judi secara umum, mengundi nasib dan setiap kegiatan yang sifatnya untung-untungan (spekulasi). Kata Maysir dan derivikansinya berulang sebanyak 44 kali dalam Al-Quran. Sedangkan kata maysir sendiri ditemukan pada QS. AlBaqarah/2:219, dan al-Maidah/5:90-91. Dalam sejarahnya praktik maysir sudah sangat mengakar dalam tradisi masyarakat dan sulit untuk dihilangkan. Al-Quran mengakui bahwa terdapat manfaat material dari maysir berupa memperoleh keuntungan besar dan harta secara mudah, namun kerusakan yang ditimbulkanna baik bersifat materi maupun immateri jauh lebih besar. Maysir merupakan transaksi yang digantungkan kepada suatu keadan yang tidak pasti dan bersifat untung-untungan. Secara ekonomi, pelarangan judi membuat investasi ke sektor produktif makin terdorong karena todak ada investasi yang digunakan ke sektor judi dan spekulatif. Perjudian merupakan bentuk investasi yang tidak produktif karena tidak dapat terkait dengan sektor riil dan tidak memberikan dampak peningkatan penawaran agregrat barang dan jasa. 
2) Gharar; secara bahasa berarti menipu, memperdaya, ketidakpastian. Gharar adalah sesuatu yang memperdayakan manusia di dalam bentuk harta, jabatan, syahwat(keinginan), dan lainya. Dalam Al-Quran kata gharar dan revisinya disebut 27 kali antara lain dalam QS. Ali Imran/3:185 dan QS. Al-anfa/8:49. AlQuran menyebut gharar ini sebagai perbuatan tercela. Gharar berarti menjalankan suatu usaha secara buta tanpa memiliki pengetahuan yang cukup, atau menjalankan suatu transaksi yang resikonya berlebihan tanpa mengetahui dengan pasti apa akibatnya atau memasuki kancah resiko tanpa memikirkan konsekuensinya. Gharar dapat terjadi pada transaksi yang objeknya tidak jelas, tidak dimiliki, tidak diketahui keberadaanya, atau tidak dapat diserahkan pada saat transaksi dilakukan kecuali diatur lain dalam syariah. Secara ekonomi, pelarangan Gharar akan mengedepankan transparasi dalam bertransaksi dan kegiatan operasional lainna dan menghindari ketidak jelasan dalam berbisnis.

3) Haram; secara bahasa berarti larangan dan penegasan. Larangan bisa timbul karena beberapa kemungkinan, yaitu dilarang oleh Tuhan dan bisa juga karena adanya pertimbangan akal. Kata haram dengan segala pecahannya disebutkan sebanyak 83 kali dalam Al-Quran antara lain QS. Al-Baqarah/2:173, QS. ANahl/16:115 dan QS. Al-Maidah/5:3. Dalam akitivitas ekonomi setiap orang diharapkan untuk menghindari semua yang haram, baik haram zatnya maupun haram selain zatnya. Umat islam diharapkan hanya memproduksi, mengkonsumsi, dan mendistribusi produk jasa yang halal saja, baik dari segi cara memperolehnya, cara mengolahnya maupun dari segi zatnya. Secara ekonomi, pelarangan yang haram akan menjamin investasi hanya dilakukan dengan cara dan produk yang menjamin kemaslahatan manusia.

4) Riba; secara bahasa berarti bertambah dan tumbuh kata Riba dengan berbagai bentuknya disebutkan 20 kali dalam Al-Quran antara lain dalam QS. Ali Imran/3:130, QS. An-Nisa'/4: 160-161, dan QS. Al-Baqarah/2: 270-280. Riba dalam sejarahnya 
merupakan praktik yang juga mengakar sangat kuat dalam tradisi masyarakat dan sangat sulit untuk dihilangkan sampai sekarang. Riba adalah penambahan pendapatan secara tidak sah (bathil) antara lain dalam transaksi pertukaran barang sejenis yang tidak sama kualitas, kuantitas, dan waktu penyerahan ( $f a d h l$ ), atau dalam transaksi pinjam-memminjam yang mempersyaratkan nasabah penerima fasilitas mengembalikan dana yang diterima melebihi pokok pinjaman karena berjalannya waktu (nasi'ah). Secara ekonomi, pelarangan riba membuat arus investasi lancar dan tidak terbatas oleh tingkat suku bunga yang menghambat arus investasi ke sektor produktif.

5) Batil; secara bahasa artinya batal, tidak sah. Dalam aktivitas jual beli Allah menegaskan manusia dilarang mengambil harta dengan cara yang Batil sebagaimana tersebut dalam QS. Al-Baqarah/2: 188. Hal ini menegaskan bahwa dalam aktivitas ekonomi tidak boleh diilakukan dengan jalan yang Bathil seperti mengurangi timbangan, mencampurkan barang rusak di antara barang yang baik untuk mendapatkan keuntungan lebih banyak, menimbun barang, menipu atau memaksa. Secara ekonomi, pelarangan Batil ini akan semakin mendorongnya berkurangnya moral hazard dalam berekonomi yang terbukti telah banyak memakan korban dan merugikan banyak pihak.

\section{Pembiayaan Syariah dan Musyarakah}

Syariah secara harfiah berarti sumber mata air yang menjadi tempat minum hewan dan manusia. Pengertian harfiah ini menjadi pengertian khusus atau isltilah dalam kajian islam, yang sering disebut syariat islam, yaitu sumber kehidupan. Syariah atau syari'at dalam pengertian sumber kehidupan ini berkembang menjadi dua istilah teknis. Pertama, syariah dalam arti sumber petunjuk kehidupan umat manusia, yaitu wahyu dalam arti al-matluw, yaitu Al-Quran dan dalam pengertian al-wahy ghair al-matluw, yaitu hadis atau sunah rasul. Kedua, syariah dalam arti petunjuk yang "diturunkan" langusung kepada umat manusia, yakni 'aql. Aql di sini mengandung pengertian 
potensi bawaan manusia yang berfungsi mengenal, mengesankan, dan mencintai Tuhan. ${ }^{5}$

Dengan demikian, syariah dalam pengertian wahyu dan dalam pengertian 'aql inilah yang menjadi sumber dan petunjuk bagi kehidupan umat manusia. Syariah dalam islam pengertian itu memungkinkan lahirnya berbagai sistem syariah dalam keseluruhan bidang kehidupan umat manusia. Oleh karena itu, sejarah membuktikan lahirnya sistem politik syariah, sistem ketatanegaraan dan pemerintahan syariah, sistem ekonomi syariah, serta sistem lainnya dalam berbagai bidang kehidupan. Sistem ekonomi syariah atau sitem ekonomi islam, sebagai suatu sistem yang merujuk pada syari'at, yaitu petunjuk wahyu, diyakini para penganutnya sebagai suatu sitem yang memiliki kekuatan dan kemampuan memakmurkan dan mensejahterakan para pengamalnya, baik muslim maupun non muslim. Ekonomi syariah diyakini sebagai sistem ekonomi yang mendapat pandangan panduan nilai dan norma kehidupan yang datang dari yang Maha Besar dan Mahaadil, Allah SWT. Tujuannya pun tentu untuk menciptakan dan mewujudkan kesejahteraan dunia akhirat dalam kehidupan masyarakat yang berkeadilan.

Dengan kata lain, sistem ekonomi syariah diyakini lebih memberikan jaminan bagi sekalian alam, sistem syariah islam bukan hanya dapat menjamin terwujudnya kesejahteraan dan keadilan dalam ruang lingkup masyarakat yang beragama islam, melainkan dapat dilaksanakan dalam semua lingkungan dan komunitas masyarakat mana pun yang secara konsisten berpegang teguh dalam melaksanakan peinsip-prinsipnya.

Selanjutnya, musyarakah secara bahasa sering pula disebut dengan syirkah yang bermakna ikhtilath (percampuran), yakni bercampurnya salah satu dari dua harta dengan harta lainnya tanpa dapat dibedakan di antara keduanya.6 Secara terminologi, musyarakah berarti akad di antara dua orang atau lebih untuk berserikat dalam

\footnotetext{
${ }^{5}$ Juhaya S.Praja,ekonomi syariah, Bandung:pustaka setia, 2012.

${ }^{6}$ Yadi Janwari, fikih lembaga keuangan

syariah,Bandung:remaja,2015, 74
}

Volume 6 No.1 Januari 2019 
modal dan keuntungan. Para fuqaha membuat definisi tentang musyarakah ini sangat bervariatif, sekalipun sesungguhnya secara substantif tidak berbeda secara signifikan. Hanafiyah menyatakan bahwa yang dimaksud dengan musyarakah adalah akad yang dilakukan oleh orang-orang yang berserikat dalam modal dan keuntungan. Malikiyyah menyatakan bahwa musyarakah adalah akad yang mengizinkan masing-masing pihak yang berserikat untuk bertasharruf pada harta yang diserahkannya beserta tetapnya hak bagi masing-masing pihak. Sedangkan Syafi'iyah menyatakan bahwa yang dimaksud dengan musyarakah adalah tetapnya hak terhadap seesuatu bagi dua rang atau lebih dengan cara yang terbesar(dalam pembagian keuntungan). Secara singkat Hanabillah mengartikan musyarakah dengan perkumpulan dalam mendapatkan hak dan tasharruf.

Musyarakah adalah akad kerjasama antara dua pihak atau lenih untuk suatu usaha tertentu, dimana masing-masing pihak memberikan kontribusi dana dengan ketentuan bahwa keuntungan dibagi berdasarkan kesepakatan;sedangkan kerugian berdasarkan kontribusi dana (PSAK 106 paragraf 04). Musyarakah merupakan syirkah dalam modal kerja bukan dalam asset modal seperti alat produksi, alat transportasi, dan asset lain.

Secara umum, musyarakah terbagi kepada dua bagian besar, yaitu syirkah al-amlak dan syirkah al-uqud. Syirkah al-amlak itu sendiri terbagi dua bagian besar, yaitu syirkah al jabr dan syirkah alikhtiyar. Sedangkan syirkah al-uqud terdiri dari empat jenis, yaitu syirkah al-mmufawadhah, syirkah al-inan, syirkah al-wujuh dan syirkah abdan.

Keuntungan (ribh) dalam musyarakah harus dibagi sesuai dengan kadar modal yang diserahkan oleh masing-masing pihak. Demikan pula pekerjaan yang dilakukan mesti dihitung sebagi dari saham yang berhak mendapatkan bagian dari keuntungan. Apabila itu semua tidak dipertimbangkan dalam pembagian keuntungan, maka hukum musyarakah menjadi batal.

Prinsip bagi hasil lain sebagai instrumen keuangan syariah sebagai alternatif bagi instrumen bunga adalah akad musyarakah. Dengan musyarakah, pihak-pihak yang terlibat dalam lembaga 
keuangan akan mendapatkan keuntungan dengan terbebas dari bunga yang diidentikkan dengan riba dalam perspektif hukum islam. Sebagai salah satu bentuk prinsip bagi hasil, maka pihak-pihak dalam musyarakah akan ikut menanggung kerugian apabila sallah satu pihak mengalami kerugian. Dengan demikian, sebagaimana dalam mudharabah, dalam musyarakah pun berlaku prinsip profit and loss sharing (keuntungan dan kerugian ditanggung bersama) di antara pihak-pihak yang melakukan akad. Adapun jenis-jenis akad Musyarakah yaitu a) Syirkah Al-Inan, memiliki arti dimana ada dua pihak atau lebih memberikan penyertaan modalnya dengan posisi yang berbeda, maka dengan bagi hasil keuntungan yang disepakati bersama dan kerugian yang diderita akan di tanggung sesuai dengan besarnya porsi modalnya masing-masing. b) Syirkah Al-mufawadah, dalam akad ini setiap mitra harus menyertakan modal yang sama nilainya untuk mendapatkan keuntungan sesuai dengan modal yng telah diberikan.

\section{Perencanaan dan Pelaksanaan Pembiayaan Musyarakah Pada Bidang Pertanian}

Musyarakah menurut Antonio, yaitu akad kerjasama antara dua pihak atau lebih untuk suatu usaha tertentu di mana masingmasing pihak memberikan kontribusi dana dengan kesepakatan bahwa keuntungsn dan resiko akan di tanggung bersama sesuai dengan kesepakatan bersama. Musyarakah merupakan syirkah dalam modala kerja, bukan dalam aset modal seperti alat produksi, alat transportasi, dan aset lainya. Hasil penelitiannya mengenai perencanaan pembiayaan musyarakah di bidang pertanian, LKMA menjelaskan bahwa sesuatu hal untuk mencapai tujuan yang sesuai menggunakan beberapa hal. Yaitu rencana dalam melakukan pembiayaan musyarakah adalah untuk mempebaiki dari hasil panen dan modalnya hanya sedikit. Para petani melakukan pinjaman atau pembiayaan musyarakah karena terhalangnya dana, dan untuk biaya-biaya penggarapan sawah yang memerlukan banyak biaya. Dalam usaha pertanian dan pedesaan, sistem bagi hasil adalah sistem yang sudah melekat dan ada sejak lama. Sistem bagi hasil juga merupakan sitem 
yang tepat dengan kondisi usaha pertanian yang sangat tergantung dengan alam dan hasil usaha yang tidak pasti. Apabila dengan sistem bunga/konvensional, justru akan memberatkan petani, karena hasil dari usaha yang tidak pasti, sedangkan sistem bunga bersifat tetap.

Akad menurut Mardani adalah kesepakatan dalam suatu perjanjian antara dua belah pihak atau lebih untuk melakukan atau tidak melakukan perbuatan tertentu. Musyarakah adalah akad kerjasama antara dua pihak memberikan kontribusi dana dengan kesepakatan bahwa keuntungan dan resiko akan ditanggung bersama sesuai dengan kesepakatan bersama. Dasar-dasar pengelolaan LKMA Amanah Mandiri dengan sitem bagi hasil.

1) Tidak menggunkan bunga, dalam pandangan beberapa agama, bunga dianggap sebagai riba yang haram atau terlarang hukumnya. Bagi islam mendasarkan pada Al-Qur'an yang menjelaskan bahwa menggunakan riba itu haram bukumnya.

2) Prinsip bagi hasil, pada dasarnya adalah penentuan proporsi berbagi untung pada saat akad dilakukan. Hal ini akan erasa lebih adil daripada bunga yang pasti ketetapannya tanpa pandang bulu apakah anggota memeng untung atau ternyata rugi. Prinsip ini juga akan menjadikan LKMA Amanah Mandiri senantiasa berorientasi pada keuntungan dan keberhasilan usaha anggota agar LKMA juga mendapatkan bagi hasil, bukan asal lempar kredit dan target bunganya saja.

3) Selain prinsip bagi hasil, LKMA Amanah Mandiri bisa menerapkan prinsip jual beli barang dngan pembayaran tangguh, yaitu pada saat benda yang diperjual belikan itu telah dimanfaatkan dan telah mengahsilkan nilai uang untuk membayar sesuai jadwal atas kesepakatan dan atas analisa usaha yang dilakukan. Hasil penelitian mengenai pelaksanaan pembiayaan musyarakah di bidang pertanian di Lembaga Keuangan Mikro Agribisnis Sekarputih adalah pertama mengikuti prosedur untuk pengajuan pembiayaan musyarakah. Yaitu pertama mengisi formulir, pengajuan pembiayaan digunakan untuk keperluan apa, bersifat jujur dan bertanggung jawab dalam menyelesaikan pembiayaan, bersedia unuk di survey di tempat usaha atau di 
rumah, mempunyai jaminan atau penjamin untuk pembiayaan dalam jumlah tertentu. Kedua pihak LKMA survey di tempat usaha atau di rumah untuk mngetahui apakah nasabah tersebut layak meminjam atau tidak. Ketiga, apabila nasabah sudah memenuhi kriteria dan sudah diperbolehkan untuk meminjam atau melakukan pembiayaan musyarakah tersebut, maka pencairan dana atau peminjaman sudah bisa dilakukan atau dana yang dipinjam sudah dapat cair. Dan peminjam menandatangani syaratsyarat tertentu dari LKMA tersebut.

Pada LKMA syarat-syarat untuk melakukan akad sudah sesuai dengan akad musyarakah, seperti halnya yang dungkapkan oleh Antonio tentang pengertian musyarakah. Disini, pelaksanaa akad sudah terpenuhi karena adanya akad antara kedua belah pihak,adanya perjanjian hitam di atas putih, yang isinya sudah sesuai dengan apa yang disepakati bersama. Adapun jenis-jenis akad musyarkah ada 2 yaitu syirkah al-inan dan syirkah al-mufawadah. Dalam hal ini, LKMA menggunakan akad musyarakah Al-Inan, dimana kedua belah pihak memberikan penyertaan modalnya dengan posisi yang berbeda, maka dengan bagi hasil keuntungan yang disepakati bersama dan kerugian yang di derita akan ditanggung sesuai dengan besarnya porsi modalnya masing-masing.

Dampak pemberian pembiayaan musyarkah pada bidang pertanian di Lembaga Keuangan Mikro Agribisnis Sekarputih adalah pemberian pembiayaan musyarakah pada bidng pertanian sangat tepat, karena dapat membantu biaya-biaya untuk pertanian tersebut. Misalnya untuk pembelian pupuk, penggarapan sawah, pengelolaan dan laian-lain. Dalam hal ini petani memerlukan banyak biaya, karena itu pembiayaan musyarakah sangat dibutuhkan bagi para petani dengan adanya pemberian pembiayaan musyarakah tersebut petani dapat melakukan kegiatan sehari-seharinya yaitu bercocok tanam seperti padi, jagung dan kedelai dapat berjalan dengan lancar karena tidak terhalang oleh biaya. Hasil panen dari bercocok tanam tersebut dapat dilihat dari hasil panen yang meningkat lebih banyak dan bagus karena menggunakan pemberian pembiayaan tersebut. Hasil 
panenannya biasanya hanya mencapai $2000 \mathrm{~kg}$ sekarang bisa mencapai $5000 \mathrm{~kg}$ per panenannya.

\section{Kesimpulan}

Berdasarkan temuan data dan analisa, peneliti dapat menyimpulkan tiga hal yaitu pertama, Perencanaan pembiayaan yang digunakan untuk pembiayaan musyarakah masih kurang, karena banyak nasabah yang belum mngerti tentang penggunaan akad musyarakah, seperti cara penyampain informasi tentang sistem bagi hasil mengenai pembiayaan musyarakah pada bidang pertanian di sekitar Lembaga Mikro Agribisnis. Meskipun petani tidak memilik sawah sendiri namun petani dapat mengajukan pembiayaan musyarakah, karena dalam sistem bagi hasil di LKMA tidak harus memiliki sawah atau lahan milik sendiri. Tentang mudahnya menggunakan pembiayaan musyarakah tersebut bagi para petani.

Kedua, pelaksaan pembiayaan musyarakah pada bidang pertanian di Lembaga Keuangan Mikro Agribisnis Sekarputih secara umum dalam pelaksanaan pembiayaan musyarakah untuk bidang pertanian sudah baik dilihat dari nasabah mengikuti prosedur yang diberikan LKMA yaitu, pengisisan formulir, pelaksanaan akad musyarakah, dan ketentuan-ketentuan dari LKMA dan adanya perjanjian hitam diatas putih. Tetapi untuk pengawasan, dalam hal ini LKMA masih kurang maksimal karena keterbatasan jumlah karyawan.

Ketiga, dampak pemberian pembiayaan musyarakah pada bidang pertanian adalah 1) petani dapat meneruskan bercocok tanannya tanpa perlu cemas terhadap modal atau biaya yang digunakan untuk pengelolaan sawah tersebut. 2) Petani bisa menghasilkan panen atau produktifitasnya lebih baik dan banyak daripada panen sebelumnya di karenakan ikut pembiayaan musyarakah di LKMA, sehingga para petani mampu untuk penggarapan sawah selanjutnya dan hasilnya bisa memuasakan.

\section{Daftar Pustaka}

Rozalinda. 2017. Fikih Ekonomi Syariah, Prinsip dan implementasinya pada sektor keuangan syariah. Rajagrafindo persada: Jakarta. 
Amin Mohammad Suma, 2013. Tafsir Ayat Ekonomi. Grafika Ofset: Jakarta

Kadir, 2013. Hukum bisnis Syariah Dalam Al-Qur'an. Amzah:Jakarta Soemitra Andri, 2014. Bank Dan Lembaga Keuangan Lainya. Kencana: Jakarta

S praja Juhaya, 2015. Ekonomi Syariah. Cv. Pustaka Setia: Bandung Satori Djam'an, 2017. Metodologi Penelitian Kualitatif. Alfabeta: Bandung

Arifin Tajul, 2014. Metode Penelitian Ekonomi Islam. Cv. Pustaka Setia: Bandung

Janwari Yadi, 2015. Fikh Lembaga Keuangan Syariah. PT. Remaja rosdakarya: Bandung

Supadie Ahmad,2013. Sistem Lembaga Keuangan Ekonomi Syariah Dalam pemberdayaan Ekonomi Rakyat. PT. Pustaka Rizki Putra: Semarang

Pusat pengajian dan pengembangan ekonomi islam, 2015. Ekonomi Islam. Kharisa Putra Utama: jakarta 